\title{
ACTA AGROBOTANICA \\ Vol. 63 (1): 77-85 \\ 2010 \\ THE EFFECT OF FOLIAR NUTRITION OF SPINACH (Spinacia oleracea L.) WITH MAGNESIUM SALTS AND UREA ON GAS EXCHANGE, LEAF YIELD AND QUALITY
}

\author{
Edward Borowski, Sławomir Michałek \\ Department of Plant Physiology, University of Life Sciences in Lublin, \\ Akademicka 15, 20-950 Lublin. Poland, \\ e-mail: slawomir.michalek@up.lublin.pl
}

Received: 13.01.2010

\begin{abstract}
In a pot experiment conducted in a phytotron, the effectiveness of foliar nutrition of spinach (Spinacia oleracea L.) with different magnesium salts with and without the addition of $0.5 \%$ $\mathrm{CO}\left(\mathrm{NH}_{2}\right)_{2}$ was studied. Magnesium was applied 3 times in the form of solutions of $\mathrm{MgSO}_{4}$ × $7 \mathrm{H}_{2} \mathrm{O}, \mathrm{Mg}\left(\mathrm{NO}_{3}\right)_{2}$ × $6 \mathrm{H}_{2} \mathrm{O}, \mathrm{MgCl}_{2}$ x $6 \mathrm{H}_{2} \mathrm{O}, \mathrm{C}_{4} \mathrm{H}_{6} \mathrm{O}_{4} \mathrm{Mg}$ x $4 \mathrm{H}_{2} \mathrm{O}$, compared to water as the control treatment. The obtained results showed that foliar feeding of spinach with inorganic magnesium salts was an efficient method for supplementing the $\mathrm{Mg}$ level in plants during the growing period. But the application of a metalo-organic complex in the form of magnesium acetate $\left(\mathrm{C}_{4} \mathrm{H}_{6} \mathrm{O}_{4} \mathrm{Mg}\right.$ x $\left.4 \mathrm{H}_{2} \mathrm{O}\right)$ at a concentration of $1.7 \%$, in spite of a similar effect on leaf $\mathrm{Mg}$ content, induced phytotoxic symptoms in the form of chlorotic and necrotic spots on the leaves. The application of the solutions of inorganic magnesium salts had a significant effect, resulting in more intensive leaf gas exchange (stomatal conductance, transpiration and photosynthesis) and an increase in leaf yield. Magnesium sulphate affected the abovementioned processes in the most effective way, while magnesium acetate had a negative impact. Foliar feeding of spinach with the magnesium salts resulted in an increased leaf content of protein, chlorophyll, carotenoids, nitrates and proline, but a decrease in vitamin $\mathrm{C}$ content. The addition of urea to the applied magnesium salt solutions increased the plant gas exchange rates and the leaf content of protein, chlorophyll, carotenoids, nitrates and proline, but it decreased the content of vitamin $\mathrm{C}$, potassium and magnesium.
\end{abstract}

Key words: Spinacia oleracea, magnesium salts, urea, foliar nutrition, gas exchange, leaf yield, leaf quality.

\section{INTRODUCTION}

Magnesium performs many diverse functions in plant cell metabolism. It occurs in the centre of the chlorophyll particle and is a cofactor of numerous enzymes involved in the processes of phosphorylation and phloem loading in leaves. An insufficient level of magnesium in plants reduces chlorophyll and carotenoid content, leaf stomatal conductance and photosynthesis rate ( $\mathrm{S} \mathrm{u} \mathrm{n}$ and $\mathrm{Pay} \mathrm{n}, 1999 ; \mathrm{H} \mathrm{ou} \mathrm{ch} \mathrm{e} \mathrm{g}$ Li u et al. 2006; D ing et al., 2008; Cakmak and $\mathrm{K}$ i r k b y ,2008). Magnesium also affects protein content in plants, since it is a stabilizer of the ribosome structure (H o u cheng Li u et al. 2006).

Since soil magnesium availability to crop plants changes under the influence of environmental conditions, in particular $\mathrm{pH}$, in the last 15-20 years foliar feeding with this nutrient has been commonly applied across Europe (Orlovius, 2001). According to numerous studies, non-root $\mathrm{Mg}$ application increases plant productivity (P inkerton and Person, 1974; B iesiada et al. 1998; Świerczewska and Sztuder, 2001; Orlovius, 2001; Hafiz and E1-Kholy, 2001; Moustafa and Omran, 2006; M o s t a fa et al. 2007; D ord a s, 2009). Under these conditions, chlorophyll and magnesium content in plants also increases (B i e s i a d a et al. 1998; Escamillo Garcia et al. 2003; Moustafa and Omran, 2006; Mostafa et al. 2007; Dord a s, 2009).

In most studies on foliar nutrition with magnesium, $\mathrm{Mg}$ was applied to plants in the form of $\mathrm{MgSO}_{4}$ $x 7 \mathrm{H}_{2} \mathrm{O}$ solution (P in kerton and Person, 1974; Świerczewska and Sztuder, 2001; Orlovius, 2001; Moustafa and Omran, 2006; Mostafa et al. 2007). But Fisher and Walker (1995) as well as Curylo (1971) found that plants absorbed magnesium much more easily from chloride or nitrate solutions than from magnesium sulphate. In the literature, there is no agreement whether it is advisable to use chelated forms of this nutrient. A general view is held that metalo-organic complexes do not 
increase the absorption of the applied nutrient compared to inorganic forms (A b a di a et al., 2002), but B e a vers et al. (1994) found a lower uptake of $\mathrm{Ca}^{++}$ by the apple fruit from Ca-EDTA than from $\mathrm{CaCl}_{2}$. Michałojć and Szewczuk (2003) report that chelates are less phytotoxic and they facilitate the movement of the applied nutrients in the plant.

Since soils in Poland are generally magnesiumpoor (M i k i c i u k et al., 2008), and at the same time leafy vegetables, including spinach, require intensive fertilization with potassium $(\mathrm{Orłowski}$ and K o ł o t a , 1999), which may impede Mg uptake from the soil (Uziak and B orowski, 1980/1981), it is advisable to undertake research on the effect of nonroot nutrition with magnesium on the pattern of gas exchange, productivity and quality of spinach leaves. Due to the fact that earlier studies showed a beneficial effect of $\mathrm{CO}\left(\mathrm{NH}_{2}\right)_{2}$ on potassium absorption by spinach leaves (B orowski and Michałek, 2009), the solutions of magnesium salts (three organic salts and one inorganic salt) were applied with and without the addition of urea.

\section{MATERIALS AND METHODS}

The experiments were conducted in a phytotron of the University of Life Sciences in Lublin in 2009, in the periods from 20 April to 12 June (1st replicate) and from 31 August to 27 October (2nd replicate). Spinach (Spinacia oleracea L.) cv. 'Matador' plants were grown in $1.5 \mathrm{dm}^{3}$ pots filled with quartz sand, without fines. The experiment was carried out using fluorescent light with the far-field flux density of ca. $200 \mu \mathrm{mol} \mathrm{x} \mathrm{m}{ }^{-2} \mathrm{x} \mathrm{s}^{-1}$, day length of 14 hours and temperature of $18^{\circ} / 15^{\circ} \mathrm{C}$ (day/night).

Each experiment comprised 50 pots, with 3 plants growing in one pot. After emergence, the plants were supplemented with $105 \mathrm{mg} \mathrm{N}-\mathrm{NO}_{3}, 118 \mathrm{mg}$ $\mathrm{K}, 16 \mathrm{mg} \mathrm{P}, 100 \mathrm{mg} \mathrm{Ca}, 32 \mathrm{mg} \mathrm{S}$ and $24 \mathrm{mg} \mathrm{Mg}$ in the form of $1 / 2$ concentration of Hoagland's medium per pot. The same medium concentrations were applied in the 2nd, 3rd and 4th weeks of plant growth; however, in the third and fourth weeks the applied medium did not contain $\mathrm{MgSO}_{4} \times 7 \mathrm{H}_{2} \mathrm{O}$. Each time, $1 \mathrm{~cm}^{3}$ of $2 \%$ ferric citrate solution and the micronutrient solution (A-Z) were applied to the pots together with the medium.

During the growing period, the plants were watered with distilled water to constant weight, maintaining substrate moisture content at a level of $70 \%$ of field water capacity (FWC). In the fifth week of growth, 10 experimental series were set up (5 pots in each), differentiated in terms of the foliar applied magnesium salts and the addition of urea, or not. The respective experimental series were sprayed with aqueous solutions of the following magnesium salts: 1) $\mathrm{H}_{2} \mathrm{O}$
- control, 2) $\mathrm{MgSO}_{4}$ × $\left.7 \mathrm{H}_{2} \mathrm{O}, 3\right) \mathrm{Mg}\left(\mathrm{NO}_{3}\right)_{2}$ × $\left.6 \mathrm{H}_{2} \mathrm{O}, 4\right)$ $\left.\mathrm{MgCl}_{2} \times 6 \mathrm{H}_{2} \mathrm{O}, 5\right) \mathrm{C}_{4} \mathrm{H}_{6} \mathrm{O}_{4} \mathrm{Mg} \times 4 \mathrm{H}_{2} \mathrm{O}$, in pure form or a mixture of the particular salts with $0.5 \% \mathrm{CO}\left(\mathrm{NH}_{2}\right)_{2}$ (experiment design - Table 1). The aqueous solutions of the abovementioned magnesium salts contained 2.0 $\mathrm{mg}$ of pure magnesium in $1 \mathrm{~cm}^{3}$. Foliar fertilization of the plants with the abovementioned magnesium salt forms was repeated in the sixth and seventh weeks of growth. The solutions were applied using a manual sprayer at an air temperature of $18^{\circ} \mathrm{C}$, just before nightfall, each time until complete moisturization of the accessible leaf surface was obtained.

After 4 days from the last spraying, measurements were made of leaf stomatal conductance for water vapour as well as of transpiration and photosynthesis rates. The measurements were made in 12 replications on fully-developed middle leaves of spinach rosettes, using a leaf microclimate control system LCA-4. During measurement recording, temperature in the measurement chamber was approx. $22^{\circ} \mathrm{C}$, while the far-field flux density approx. $200 \mu \mathrm{mol} \mathrm{x} \mathrm{m}{ }^{-2}$ $\mathrm{x} \mathrm{s}^{-1}$. Concurrently, leaf samples were collected to determine the content of protein, nitrates, chlorophyll " $a+b$ ", carotenoids, vitamin C, and proline. The content of the abovementioned compounds was determined using the following methods: protein according to Kjeldahl; nitrates according to C a t a $1 \mathrm{~d}$ o et al. (1975); chlorophyll " $a+b$ " according to Arno n (1949); carotenoids according to Britton (1985); vitamin C according to Pijan owski et al. (1973), and proline according to B a te s et al. (1973). Subsequently, average leaf fresh weight per plant was determined, and after drying potassium content in leaf dry weight was identified using the atomic absorption method and an atomic absorption system (AAS), while magnesium content was determined colourimetrically using titan yellow. Prior to the analysis, fresh leaves were washed in distilled water. This paper presents the mean results obtained in two experiments. These data were subjected to statistical analysis using double cross-classification, determining the significance of differences by Tukey's test at the level of significance $\alpha=0.05$.

\section{RESULTS AND DISCUSSION}

The results presented in Table 1 show that all the foliar applied inorganic magnesium salts had a significantly beneficial effect on stomatal conductance of spinach leaves. Magnesium sulphate showed the strongest effect, increasing stomatal conductance more than 3.5 times relative to the control, while magnesium chloride had relatively the weakest effect, as this increase was only 1.5 times. But the applied magnesium acetate had an adverse impact on stomatal conductance, although it was within the statistical error. The effect of the applied magnesium salts on stomatal 
conductance of spinach leaves determined the pattern of transpiration and photosynthesis, which seems to be fully understandable. The obtained results demonstrate that under the experimental conditions the water vapour diffused most intensely from the leaves, whereas $\mathrm{CO}_{2}$ to the leaf mesophyll, in the plants fertilized with $\mathrm{MgSO}_{4} \times 7 \mathrm{H}_{2} \mathrm{O}$, significantly more poorly in those foliar fed with $\mathrm{Mg}\left(\mathrm{NO}_{3}\right)_{2} \times 6 \mathrm{H}_{2} \mathrm{O}$, while the diffusion was the poorest in the plants fertilized with $\mathrm{MgCl}_{2}$ $x 6 \mathrm{H}_{2} \mathrm{O}$. But the transpiration and photosynthesis rates in the leaves of the plants sprayed with $\mathrm{C}_{4} \mathrm{H}_{6} \mathrm{O}_{4} \mathrm{Mg}$ $\mathrm{x} 4 \mathrm{H}_{2} \mathrm{O}$ were significantly lower relative to the control treatment. The beneficial effect of the inorganic magnesium salts on the gas exchange processes in spinach leaves undoubtedly results from increased magnesium content in the leaves under these conditions. The results contained in Table 6 indicate that foliar application of the salts increased magnesium content more than $53 \%$ relative to the control. Magnesium content in the spinach leaves treated with magnesium acetate also increased at the same level, but in spite of this fact the effect of this salt on the gas exchange parameters in question was opposite (Table 6). This is probably related to the fact that this salt showed phytotoxic effect in the plants, since it induced the appearance of yellow spots already after the first application, which changed into necrotic spots after the second and third sprayings (Fig. 1).

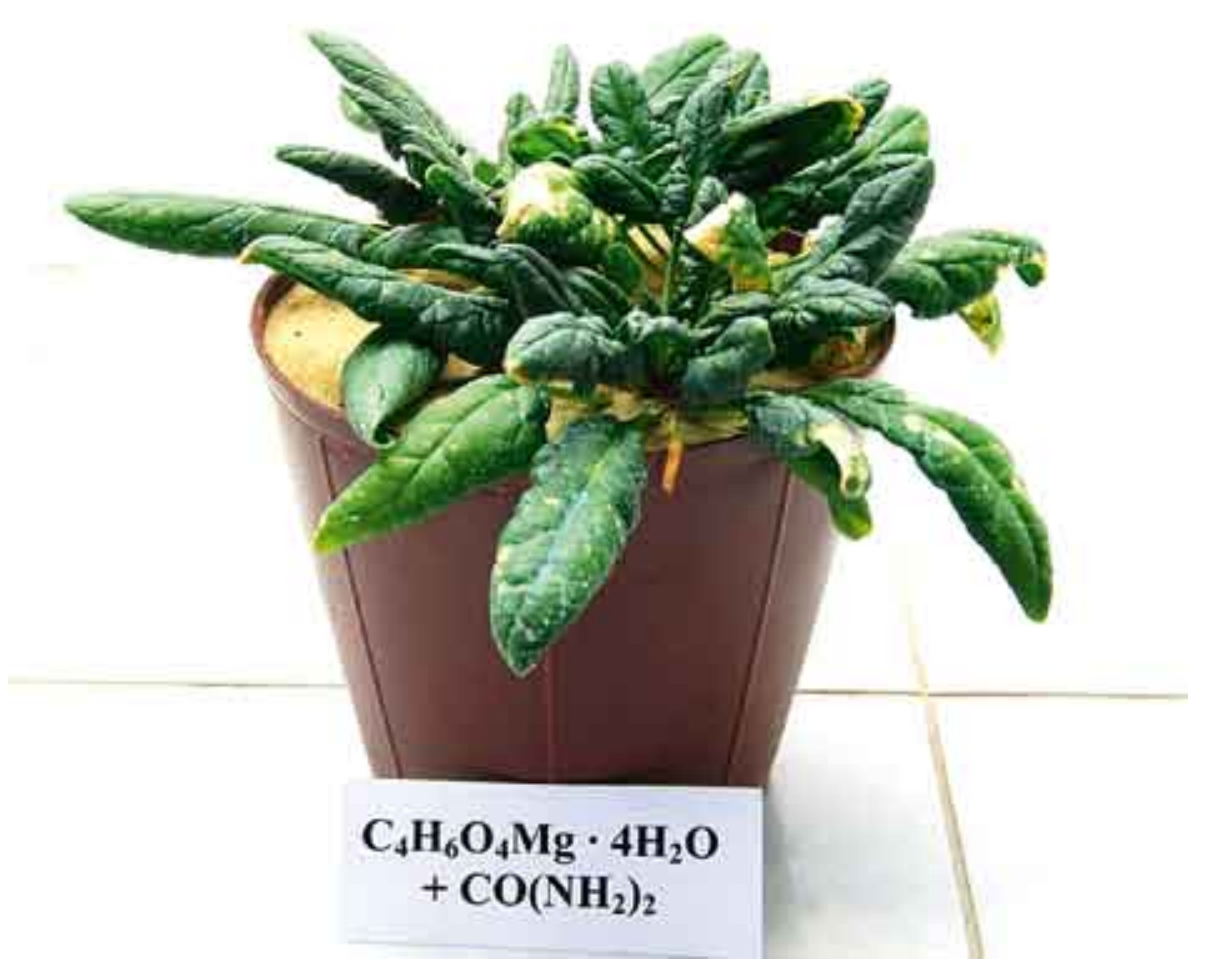

Fig. 1. Apperance of Spinacia oleracea L. plants foliar nutrited with $1.7 \%$ magnezium octate with addition $0.5 \%$ urea

In the literature, there is a lack of data on the effect of foliar feeding of plants with magnesium on the gas exchange processes in them. However, the papers by Sun and Payn (1999), Houcheng Liu et al. (2006), Ding et al. (2008), Cakmak and K i r k b y (2008) show that magnesium deficiency in plants strongly reduces leaf stomatal conductance and $\mathrm{CO}_{2}$ assimilation. The addition of the inorganic magnesium salts $\mathrm{CO}\left(\mathrm{NH}_{2}\right)_{2}$ to the solution significantly increased leaf stomatal conductance, transpiration and photosynthesis. But the addition of urea to the magnesium acetate solution had a converse effect, since in this case the value of the parameters in question decreased (Tables 1 and 2).
The results shown in Table 2 demonstrate that all the applied magnesium salts had a significantly beneficial effect on fresh weight yield of spinach leaves. The highest yield was produced by the plants foliar fed with magnesium chloride and nitrate, while the lowest yield was obtained from those fertilized with magnesium acetate, but these differences were insignificant. Undoubtedly, spinach productivity should be linked to the effect of feeding with the magnesium salts on plant photosynthesis. The fact that the plants treated with $\mathrm{C}_{4} \mathrm{H}_{6} \mathrm{O}_{4} \mathrm{Mg} \times 4 \mathrm{H}_{2} \mathrm{O}$ produced higher yields than those treated with $\mathrm{H}_{2} \mathrm{O}$ may arouse certain doubts in the situation where $\mathrm{CO}_{2}$ assimilation in these plants was significantly lower compared to the control treatment. 
The results given in Table 2 relate to the rate of photosynthesis per leaf area unit, whereas the total leaf area of the plants fed with magnesium acetate was similar to the leaf area of the plants fertilized with the other magnesium salts. Hence, a significantly higher leaf yield of the plants treated with $\mathrm{C}_{4} \mathrm{H}_{6} \mathrm{O}_{4} \mathrm{Mg} \times 4 \mathrm{H}_{2} \mathrm{O}$ compared to the control, but lower than in those sprayed with the other magnesium salts, results from the reduced rate of photosynthesis and the exclusion of a part of the leaf surface area (roughly estimated about 10\%) from active photosynthesis as a result of necrotic changes.

Table 1

Effect of magnesium salts and addition of urea in foliar application on stomatal conductance and intensity of transpiration of spinach leaves

\begin{tabular}{|c|c|c|c|c|c|c|}
\hline \multirow{2}{*}{$\begin{array}{l}\text { Magnesium } \\
\text { salts }\end{array}$} & \multicolumn{2}{|c|}{ Solution } & \multirow[b]{2}{*}{ Mean } & \multicolumn{2}{|c|}{ Solution } & \multirow[b]{2}{*}{ Mean } \\
\hline & $\begin{array}{c}\text { without } \\
\text { urea }\end{array}$ & $\begin{array}{l}\text { with } \\
\text { urea }\end{array}$ & & $\begin{array}{c}\text { without } \\
\text { urea }\end{array}$ & $\begin{array}{l}\text { with } \\
\text { urea }\end{array}$ & \\
\hline & \multicolumn{3}{|c|}{ conductance $\left(\mathrm{mol} \mathrm{H}_{2} \mathrm{O} \times \mathrm{m}^{-2} \times \mathrm{s}^{-1}\right)$} & \multicolumn{3}{|c|}{ transpiration $\left(\mathrm{mmol} \mathrm{H}_{2} \mathrm{O} \times \mathrm{m}^{-2} \times \mathrm{s}^{-1}\right)$} \\
\hline Control $\left(\mathrm{H}_{2} \mathrm{O}\right)$ & 0.05 & 0.10 & 0.07 & 1.71 & 1.59 & 1.65 \\
\hline $\mathrm{MgSO}_{4} \times 7 \mathrm{H}_{2} \mathrm{O}$ & 0.22 & 0.28 & 0.25 & 2.62 & 2.83 & 2.72 \\
\hline $\mathrm{Mg}\left(\mathrm{NO}_{3}\right)_{2} \times 6 \mathrm{H}_{2} \mathrm{O}$ & 0.18 & 0.20 & 0.19 & 2.28 & 2.66 & 2.47 \\
\hline $\mathrm{MgCl}_{2} \times 6 \mathrm{H}_{2} \mathrm{O}$ & 0.10 & 0.12 & 0.11 & 2.18 & 2.25 & 2.21 \\
\hline $\mathrm{C}_{4} \mathrm{H}_{6} \mathrm{O}_{4} \mathrm{Mg} \times 4 \mathrm{H}_{2} \mathrm{O}$ & 0.06 & 0.05 & 0.05 & 1.27 & 1.08 & 1.17 \\
\hline Mean & 0.12 & 0.15 & & 2.01 & 2.08 & \\
\hline \multicolumn{2}{|c|}{$\mathrm{LSD}_{0.05}$ for salts } & \multicolumn{2}{|l|}{0.02} & \multicolumn{3}{|c|}{0.04} \\
\hline \multicolumn{2}{|c|}{$\mathrm{LSD}_{0.05}$ for urea } & \multicolumn{2}{|l|}{0.01} & \multicolumn{3}{|c|}{0.02} \\
\hline \multicolumn{2}{|c|}{$\mathrm{LSD}_{0.05}$ for salts $\times$ urea } & 0.02 & & & 0,06 & \\
\hline
\end{tabular}

Table 2

Effect of magnesium salts and addition of urea in foliar application on intensity of photosynthesis and on yield of fresh mass of spinach leaves

\begin{tabular}{|c|c|c|c|c|c|c|}
\hline \multirow{2}{*}{$\begin{array}{l}\text { Magnesium } \\
\text { salts }\end{array}$} & \multicolumn{2}{|c|}{ Solution } & \multirow[b]{2}{*}{ Mean } & \multicolumn{2}{|c|}{ Solution } & \multirow[b]{2}{*}{ Mean } \\
\hline & $\begin{array}{c}\text { without } \\
\text { urea }\end{array}$ & $\begin{array}{l}\text { with } \\
\text { urea }\end{array}$ & & $\begin{array}{c}\text { without } \\
\text { urea }\end{array}$ & $\begin{array}{l}\text { with } \\
\text { urea }\end{array}$ & \\
\hline & \multicolumn{3}{|c|}{ photosynthesis $\left(\mu \mathrm{mol} \mathrm{CO} \mathrm{CO}_{2} \times \mathrm{m}^{-2} \times \mathrm{s}^{-1}\right)$} & \multicolumn{3}{|c|}{ fresh mass of leaves $\left(\mathrm{g} \times\right.$ plant $\left.^{-1}\right)$} \\
\hline Control $\left(\mathrm{H}_{2} \mathrm{O}\right)$ & 2.93 & 3.97 & 3.45 & 8.28 & 8.65 & 8.47 \\
\hline $\mathrm{MgSO}_{4} \times 7 \mathrm{H}_{2} \mathrm{O}$ & 6.38 & 7.11 & 6.74 & 16.93 & 16.00 & 16.47 \\
\hline $\mathrm{Mg}\left(\mathrm{NO}_{3}\right)_{2} \times 6 \mathrm{H}_{2} \mathrm{O}$ & 5.36 & 6.62 & 5.99 & 17.53 & 16.94 & 17.24 \\
\hline $\mathrm{MgCl}_{2} \times 6 \mathrm{H}_{2} \mathrm{O}$ & 4.69 & 5.20 & 4.94 & 17.68 & 17.58 & 17.63 \\
\hline $\mathrm{C}_{4} \mathrm{H}_{6} \mathrm{O}_{4} \mathrm{Mg} \times 4 \mathrm{H}_{2} \mathrm{O}$ & 3.15 & 3.09 & 3.12 & 14.56 & 14.63 & 14.60 \\
\hline Mean & 4.50 & 5.20 & & 15.00 & 14.76 & \\
\hline \multicolumn{2}{|c|}{$\mathrm{LSD}_{0.05}$ for salts } & 0.25 & & & 4.55 & \\
\hline \multicolumn{2}{|c|}{$\mathrm{LSD}_{0.05}$ for urea } & 0.11 & & & n.s & \\
\hline \multicolumn{2}{|c|}{$\mathrm{LSD}_{0.05}$ for salts $\times$ urea } & 0.41 & & & 7.52 & \\
\hline
\end{tabular}


The addition of urea to the foliar applied magnesium salts had no effect on fresh weight yield of leaves (Table 2). The results of numerous studies on different plant species in which foliar application of magnesium was used, most frequently in the form of $\mathrm{MgSO}_{4} \times 7 \mathrm{H}_{2} \mathrm{O}$, confirm the beneficial effect of this treatment on the yield of the vegetative parts of plants (Pinkerton and Person, 1974; Biesiada et al. 1998; Świerczewska and Sztudar, 2001; Orlovius, 2001; Hafiz and E1-Kholy, 2001; Moustafa and Omran, 2006; Mostafa etal. 2007; D ordas, 2009).

As shown in the data collected in Table 3, foliar application of magnesium increased leaf protein content by an average of $46.7 \%$ compared to the control. In this respect, $\mathrm{Mg}\left(\mathrm{NO}_{3}\right)_{2} \times 6 \mathrm{H}_{2} \mathrm{O}$ stand out among the other salts used. This was undoubtedly attributable to the fact that this salt was a source of not only $\mathrm{Mg}^{++}$ions, but also of nitrogen used only partially for protein synthesis, primarily as a source of nitrates in the leaves. It seems that the similar effect of the addition of urea to the solutions of the applied magnesium salts on the value of the trait in question should also be explained by this fact. The beneficial effect of foliar Mg application on protein content probably results from the fact that magnesium increased the production of carbon skeletons in the leaves (Table 2), but it was also due to the fact that magnesium stabilises the structure of ribosomes $(\mathrm{Ho}$ ucheng Liu et al. 2006; Ding et al. 2008).
In addition to high leaf protein content, the spinach plants foliar fed with magnesium also had high nitrate content (Table 3). This applied to all the series, except for the control, in particular in the plants fed with $\mathrm{Mg}\left(\mathrm{NO}_{3}\right)_{2} \times 6 \mathrm{H}_{2} \mathrm{O}$ and $\mathrm{C}_{4} \mathrm{H}_{6} \mathrm{O}_{4} \mathrm{Mg} \times 4 \mathrm{H}_{2} \mathrm{O}$ in which $\mathrm{NO}_{3}^{-}$content was (respectively) 6.3 and 7.1 times higher compared to the control treatment. Such high leaf nitrate content resulted from the application of a double concentration of Hoagland's medium as the primary source of nitrogen only in the form of $\mathrm{NO}_{3}$ at an amount of $1245.2 \mathrm{mg} \mathrm{NO}_{3} \times \mathrm{dm}^{-3}$, but as it seems, also from the stimulating effect of the supplied $\mathrm{Mg}$ ions on nitrate transport from the roots to the leaves. However, the accumulated $\mathrm{NO}_{3}^{-}$ions were not sufficiently reduced in the leaves, probably due to low light intensity and a short growing period of spinach. Given the above, the very high content of $\mathrm{NO}_{3}^{-}$in the case of foliar treatment of the plants with $\mathrm{Mg}\left(\mathrm{NO}_{3}\right)_{2} \times 6 \mathrm{H}_{2} \mathrm{O}$ is certainly understandable, but it is difficult to explain the even higher content of these compounds in the plants foliar fed with $\mathrm{C}_{4} \mathrm{H}_{6} \mathrm{O}_{4} \mathrm{Mg} \times 4 \mathrm{H}_{2} \mathrm{O}$ than in the case of fertilization with magnesium nitrate. The addition of urea to the application solution induced an average threefold increase in $\mathrm{NO}_{3}{ }^{-}$content in the leaves, which indicates that the direct supply of reduced nitrogen forms to these organs slightly increased protein synthesis and clearly inhibited nitrate reduction (Table 3).

Table 3

Effect of magnesium salts and addition of urea in foliar application on content of crude protein and nitrates in fresh mass of spinach leaves

\begin{tabular}{|c|c|c|c|c|c|}
\hline \multirow{2}{*}{$\begin{array}{l}\text { Magnesium } \\
\text { salts }\end{array}$} & \multicolumn{2}{|c|}{ Solution } & \multirow{2}{*}{ Mean } & \multicolumn{2}{|c|}{ Solution } \\
\hline & $\begin{array}{c}\text { without } \\
\text { urea }\end{array}$ & $\begin{array}{l}\text { with } \\
\text { urea }\end{array}$ & & $\begin{array}{c}\text { without } \\
\text { urea }\end{array}$ & $\begin{array}{l}\text { with } \\
\text { urea }\end{array}$ \\
\hline & \multicolumn{3}{|c|}{ protein $\left(m g \times g^{-1}\right.$ f.m.) } & \multicolumn{2}{|c|}{ nitrates $\left(\mu \mathrm{gNO}_{3} \times \mathrm{g}^{-1} \mathrm{f} . \mathrm{m}.\right)$} \\
\hline Control $\left(\mathrm{H}_{2} \mathrm{O}\right)$ & 19.01 & 23.62 & 21.31 & 241.8 & 270.2 \\
\hline $\mathrm{MgSO}_{4} \times 7 \mathrm{H}_{2} \mathrm{O}$ & 28.69 & 33.12 & 30.90 & 402.2 & 1024.7 \\
\hline $\mathrm{Mg}\left(\mathrm{NO}_{3}\right)_{2} \times 6 \mathrm{H}_{2} \mathrm{O}$ & 32.04 & 33.08 & 32.56 & 655.6 & 2550.8 \\
\hline $\mathrm{MgCl}_{2} \times 6 \mathrm{H}_{2} \mathrm{O}$ & 29.00 & 32.33 & 30.66 & 435.2 & 1564.6 \\
\hline $\mathrm{C}_{4} \mathrm{H}_{6} \mathrm{O}_{4} \mathrm{Mg} \times 4 \mathrm{H}_{2} \mathrm{O}$ & 30.25 & 31.60 & 30.92 & 920.1 & 2704.9 \\
\hline Mean & 27.80 & 30.75 & & 531.0 & 1623,0 \\
\hline \multicolumn{2}{|c|}{$\mathrm{LSD}_{0.05}$ for salts } & - & & & 317.1 \\
\hline \multicolumn{2}{|c|}{$\mathrm{LSD}_{0.05}$ for urea } & - & & & 139.8 \\
\hline \multicolumn{2}{|c|}{$\mathrm{LSD}_{0.05}$ for salts $\times$ urea } & - & & & 531.1 \\
\hline
\end{tabular}


Supplementary feeding of the plants with the magnesium salts applied exerted a beneficial effect on chlorophyll " $a+b$ " and carotenoid content in spinach leaves (Table 4). Magnesium sulphate and nitrate had the most beneficial effect on the traits in question, magnesium chloride had a less beneficial effect, since its impact on carotenoid content proved to be statistically insignificant, while magnesium acetate had the least beneficial effect, as it did not increase significantly the content of any of the photosynthetic pigments concerned. It seems that the least effect of $\mathrm{C}_{4} \mathrm{H}_{6} \mathrm{O}_{4} \mathrm{Mg} \times$ $4 \mathrm{H}_{2} \mathrm{O}$ on chlorophyll and carotenoid content should be attributable to the occurrence of chlorotic and necrotic spots on the leaves (Fig. 1). The beneficial effect of su- pplementary feeding of the plants with magnesium on leaf chlorophyll content undoubtedly results from the proportion of ions of this metal in the particle structure of this compound. The correlations found in the present experiments also find confirmation in the studies of Biesiada et al. (1988), Hafiz and ElKholy (2001), Moustafa and Omran (2006), Mostafa et al. (2007) and Dordas (2009). The addition of urea to the magnesium salt solutions significantly increased the content of the photosynthetic pigments in question, which should be attributable to the beneficial effect of $\mathrm{CO}\left(\mathrm{NH}_{2}\right)_{2}$ on leaf protein content, since chlorophyll and carotenoids are found in the green organs of plants in the form of complexes with protein.

Table 4

Effect of magnesium salts and addition of urea in foliar application on content of chlorophyll ,a+b” and carotenoids in leaves of spinach

\begin{tabular}{|c|c|c|c|c|c|c|}
\hline \multirow{2}{*}{$\begin{array}{l}\text { Magnesium } \\
\text { salts }\end{array}$} & \multicolumn{2}{|c|}{ Solution } & \multirow[b]{2}{*}{ Mean } & \multicolumn{2}{|c|}{ Solution } & \multirow[b]{2}{*}{ Mean } \\
\hline & $\begin{array}{c}\text { without } \\
\text { urea }\end{array}$ & $\begin{array}{l}\text { with } \\
\text { urea }\end{array}$ & & $\begin{array}{c}\text { without } \\
\text { urea }\end{array}$ & $\begin{array}{l}\text { with } \\
\text { urea }\end{array}$ & \\
\hline & \multicolumn{3}{|c|}{ chlorophyll (mg× $\left.\mathrm{g}^{-1} \mathrm{f} . \mathrm{m}.\right)$} & \multicolumn{3}{|c|}{ carotenoids (mg× $\left.\mathrm{g}^{-1} \mathrm{f} . \mathrm{m}.\right)$} \\
\hline Control $\times\left(\mathrm{H}_{2} \mathrm{O}\right)$ & 1,01 & 1,36 & 1,19 & 0,17 & 0,20 & 0,19 \\
\hline $\mathrm{MgSO}_{4} \times 7 \mathrm{H}_{2} \mathrm{O}$ & 1,79 & 2,43 & 2,11 & 0,26 & 0,32 & 0,29 \\
\hline $\mathrm{Mg}\left(\mathrm{NO}_{3}\right)_{2} \times 6 \mathrm{H}_{2} \mathrm{O}$ & 1,87 & 2,23 & 2,05 & 0,24 & 0,29 & 0,27 \\
\hline $\mathrm{MgCl}_{2} \times 6 \mathrm{H}_{2} \mathrm{O}$ & 1,40 & 1,67 & 1,53 & 0,19 & 0,22 & 0,21 \\
\hline $\mathrm{C}_{4} \mathrm{H}_{6} \mathrm{O}_{4} \mathrm{Mg} \times 4 \mathrm{H}_{2} \mathrm{O}$ & 1,51 & 1,28 & 1,40 & 0,20 & 0,18 & 0,19 \\
\hline Mean & 1,52 & 1,79 & & 0,21 & 0,24 & \\
\hline \multicolumn{2}{|c|}{$\mathrm{LSD}_{0.05}$ for salts } & 0.32 & & & 0.04 & \\
\hline \multicolumn{2}{|c|}{$\mathrm{LSD}_{0.05}$ for urea } & 0.14 & & & 0.02 & \\
\hline \multicolumn{2}{|c|}{$\mathrm{LSD}_{0.05}$ for salts $\times$ urea } & 0.53 & & & n.s. & \\
\hline
\end{tabular}

The magnesium salts applied had a different effect on vitamin $\mathrm{C}$ content than on pigment content (Table 5). The leaves of the control plants contained the largest amount of vitamin C, while foliar application of the magnesium salts significantly decreased the content of this substance. The addition of urea to the applied solutions had a similar effect. It is difficult to explain the found correlation; in particular given the fact that $\mathrm{Houcheng} \mathrm{Liu} \mathrm{et} \mathrm{al.} \mathrm{(2006)} \mathrm{found} \mathrm{that} \mathrm{high} \mathrm{Mg}$ content in Chinese cabbage promoted the synthesis of vitamin C. It seems that this may be associated with the "thinning effect", since fresh weight yield of the spinach leaves fed with $\mathrm{Mg}$ was nearly twice higher than in the control plants.

The results presented in Table 5 show that foliar nutrition of spinach with magnesium increased the leaf content of non-protein amino acids, in this case proline; however, a significant increase occurred only in the case when magnesium acetate was applied. The addition of $\mathrm{CO}\left(\mathrm{NH}_{2}\right)_{2}$ to the applied salt solutions also significantly increased the leaf content of this amino acid. These data indicate that magnesium acetate itself, and even more so with the addition of urea, induced stress, which is fully confirmed by the intensified occurrence of chlorotic and necrotic spots on the leaves (Fig. 1).

Foliar application of the magnesium salt solutions significantly increased leaf $\mathrm{Mg}$ content, in spite of a sufficient content, as it seems, of this metal in the leaves of the control plants (H a i le s et al. 1997). But the uptake of magnesium by the leaves from the applied inorganic $\mathrm{Mg}$ salts and magnesium acetate was on a similar level. These data do not confirm the thesis that the penetration of this nutrient applied to plants in chelate form reduces its absorption (B e a v e r s et al. 1994), but rather that the absorption of this nutrient from solutions of inorganic and metalo-organic salts is similar (A badia et al. 2002). 
Table 5

Effect of magnesium salts and addition of urea in foliar application on content of vitamin C and proline in leaves of spinach

\begin{tabular}{|c|c|c|c|c|c|c|}
\hline \multirow{2}{*}{$\begin{array}{l}\text { Magnesium } \\
\text { salts }\end{array}$} & \multicolumn{2}{|c|}{ Solution } & \multirow[b]{2}{*}{ Mean } & \multicolumn{2}{|c|}{ Solution } & \multirow[b]{2}{*}{ Mean } \\
\hline & $\begin{array}{c}\text { without } \\
\text { urea }\end{array}$ & $\begin{array}{l}\text { with } \\
\text { urea }\end{array}$ & & $\begin{array}{c}\text { without } \\
\text { urea }\end{array}$ & $\begin{array}{l}\text { with } \\
\text { urea }\end{array}$ & \\
\hline & \multicolumn{3}{|c|}{ vitamin $C\left(m g \times 100 g^{-1} f . m.\right)$} & \multicolumn{3}{|c|}{ proline ( $\left.\mu g \times g^{-1} f . m.\right)$} \\
\hline Control $\left(\mathrm{H}_{2} \mathrm{O}\right)$ & 61.19 & 66.21 & 63.70 & 32.55 & 37.05 & 34.80 \\
\hline $\mathrm{MgSO}_{4} \times 7 \mathrm{H}_{2} \mathrm{O}$ & 55.49 & 40.95 & 48.22 & 40.92 & 50.99 & 45.95 \\
\hline $\mathrm{Mg}\left(\mathrm{NO}_{3}\right)_{2} \times 6 \mathrm{H}_{2} \mathrm{O}$ & 48.10 & 44.72 & 46.41 & 38.75 & 51.46 & 45.10 \\
\hline $\mathrm{MgCl}_{2} \times 6 \mathrm{H}_{2} \mathrm{O}$ & 47.46 & 41.28 & 44.37 & 35.96 & 50.38 & 43.17 \\
\hline $\mathrm{C}_{4} \mathrm{H}_{6} \mathrm{O}_{4} \mathrm{Mg} \times 4 \mathrm{H}_{2} \mathrm{O}$ & 49.91 & 41.64 & 45.78 & 50.53 & 100.44 & 75.48 \\
\hline Mean & 52.43 & 46.96 & & 39.74 & 58.06 & \\
\hline \multicolumn{2}{|c|}{$\mathrm{LSD}_{0.05}$ for salts } & \multicolumn{2}{|l|}{5.10} & \multicolumn{3}{|c|}{10.97} \\
\hline \multicolumn{2}{|c|}{$\mathrm{LSD}_{0.05}$ for urea } & \multicolumn{2}{|l|}{2.27} & \multicolumn{3}{|c|}{4.82} \\
\hline \multicolumn{2}{|c|}{$\mathrm{LSD}_{0.05}$ for salts $\times$ urea } & \multicolumn{2}{|l|}{8.41} & \multicolumn{3}{|c|}{18.38} \\
\hline
\end{tabular}

Increased magnesium content in the spinach leaves foliar fertilized with this nutrient did not have a clear effect on potassium accumulation in them. $\mathrm{K}^{+}$content in the leaves of the plants fertilized with $\mathrm{Mg}\left(\mathrm{NO}_{3}\right)_{2} \times 6 \mathrm{H}_{2} \mathrm{O}$ was significantly lower, but in the case of $\mathrm{C}_{4} \mathrm{H}_{6} \mathrm{O}_{4} \mathrm{Mg} \times 4 \mathrm{H}_{2} \mathrm{O}$ it was significantly higher than in the control, while it did not differ in the plants fed with $\mathrm{MgSO}_{4} \times 7 \mathrm{H}_{2} \mathrm{O}$ and $\mathrm{MgCl}_{2} \times 6 \mathrm{H}_{2} \mathrm{O}$. The addition of urea to the salt solutions reduced the percentage content of $\mathrm{K}$ and $\mathrm{Mg}$ in leaves (Table 6).

Table 6

Effect of magnesium salts and addition of urea in foliar application on content of potassium and magnesium in dry mass of spinach leaves

\begin{tabular}{|c|c|c|c|c|c|c|}
\hline \multirow{2}{*}{$\begin{array}{l}\text { Magnesium } \\
\text { salts }\end{array}$} & \multicolumn{2}{|c|}{ Solution } & \multirow[b]{2}{*}{ Mean } & \multicolumn{2}{|c|}{ Solution } & \multirow[b]{2}{*}{ Mean } \\
\hline & $\begin{array}{c}\text { without } \\
\text { urea }\end{array}$ & $\begin{array}{l}\text { with } \\
\text { urea }\end{array}$ & & $\begin{array}{c}\text { without } \\
\text { urea }\end{array}$ & $\begin{array}{l}\text { with } \\
\text { urea }\end{array}$ & \\
\hline & \multicolumn{3}{|c|}{ potassium (\%) } & \multicolumn{3}{|c|}{ magnesium (\%) } \\
\hline Control $\left(\mathrm{H}_{2} \mathrm{O}\right)$ & 5.93 & 5.14 & 5.53 & 0.33 & 0.31 & 0.32 \\
\hline $\mathrm{MgSO}_{4} \times 7 \mathrm{H}_{2} \mathrm{O}$ & 5.69 & 5.17 & 5.43 & 0.49 & 0.49 & 0.49 \\
\hline $\mathrm{Mg}\left(\mathrm{NO}_{3}\right)_{2} \times 6 \mathrm{H}_{2} \mathrm{O}$ & 5.39 & 4.73 & 5.06 & 0.51 & 0.47 & 0.49 \\
\hline $\mathrm{MgCl}_{2} \times 6 \mathrm{H}_{2} \mathrm{O}$ & 5.99 & 5.06 & 5.52 & 0.50 & 0.47 & 0.48 \\
\hline $\mathrm{C}_{4} \mathrm{H}_{6} \mathrm{O}_{4} \mathrm{Mg} \times 4 \mathrm{H}_{2} \mathrm{O}$ & 6.25 & 5.93 & 6.09 & 0.50 & 0.47 & 0.48 \\
\hline Mean & 5.85 & 5.21 & & 0.47 & 0.44 & \\
\hline \multicolumn{2}{|c|}{$\mathrm{LSD}_{0.05}$ for salt } & \multicolumn{2}{|l|}{0.13} & \multicolumn{3}{|c|}{0.03} \\
\hline \multicolumn{2}{|c|}{$\mathrm{LSD}_{0.05}$ for urea } & \multicolumn{2}{|l|}{0.06} & \multicolumn{3}{|c|}{0.01} \\
\hline \multicolumn{2}{|c|}{$\mathrm{LSD}_{0.05}$ for salt $\times$ urea } & \multicolumn{2}{|l|}{0.21} & \multicolumn{3}{|c|}{ n.s. } \\
\hline
\end{tabular}




\section{CONCLUSIONS}

1. Foliar nutrition of spinach with inorganic magnesium salts $\left(\mathrm{MgSO}_{4} \times 7 \mathrm{H}_{2} \mathrm{O}, \mathrm{Mg}\left(\mathrm{NO}_{3}\right)_{2} \times 6 \mathrm{H}_{2} \mathrm{O}\right.$ and $\left.\mathrm{MgCl}_{2} \times 6 \mathrm{H}_{2} \mathrm{O}\right)$ is an efficient method for supplementing the $\mathrm{Mg}$ level during the growing period. The application of a metalo-organic complex in the form of magnesium acetate $\left(\mathrm{C}_{4} \mathrm{H}_{6} \mathrm{O}_{4} \mathrm{Mg} \mathrm{x} 4 \mathrm{H}_{2} \mathrm{O}\right)$ at a concentration of $1.7 \%$, in spite of a similar effect on leaf $\mathrm{Mg}$ content, induced phytotoxic symptoms in the form of chlorotic and necrotic spots on the leaves.

2. The application of the solutions of inorganic magnesium salts had a significant effect, resulting in more intensive leaf gas exchange processes - stomatal conductance, transpiration and photosynthesis, as well as in an increase in leaf yield. Magnesium sulphate affected the abovementioned processes in the most effective way, while magnesium acetate had a negative impact.

3. Foliar feeding of spinach with the magnesium salts resulted in an increased leaf content of protein, chlorophyll, carotenoids, nitrates and proline as well as in a decrease in vitamin $C$ content in leaves.

4. The addition of urea to the applied magnesium salt solutions increased the plant gas exchange rates and the leaf content of protein, chlorophyll, carotenoids, nitrates and proline, but it decreased the content of vitamin $\mathrm{C}$, potassium and magnesium.

\section{REFERENCES}

Abadia J., Alvarez-Fernandez A., Morales F., Sanz M., Abadia A., 2002. Correction of iron chlorosis by foliar spray. Acta Hort. 594: 115-122.

A rnon D.J., 1949. Cooper enzymes in isolated chloroplasts: Polyphenoloxidase in Beta vulgaris. Plant Physiol. 24: 1-15.

Bates L.S., Waldren R.R., Teare J.D., 1973. Rapid determination of free proline for water - stress studies. Plant Soil, 39: 205-207.

Beavers W.B., Sams C.E., Conway W.S., B rown G.A., 1994. Calcium source affects calcium content, firmness and degree of injury of apples during storage. HortScience, 29: 1520-1523.

Biesiada A., Kołota E., Chohura P., 1998. The possibility of improving the biological value of leafy vegetable yields as a result of soil and foliar fertilization with magnesium. Rocz. Akad. Rol. w Poznaniu, Ogrodnictwo, 27: 19-25.

Borowski E., Michałek S., 2009. The effect of foliar feeding of potassium salts and urea in spinach on gas exchange, leaf yield and quality. Acta Agrobot. 62(1): 155-162.

Britton G., 1985. General carotenoid methods. Methods Enzymol. 111: 113-114.
Cakmak J., Kirkby E.A., 2008. Role of magnesium in carbon partitioning and alleviating photooxidative damage. Physiol. Plant. 133(4): 692-704.

Cataldo D.A., Harocn M., Schrader L.E., Youngs V.L., 1975. Rapid colorimetric determination of nitrate in plant tissue by nitration of salicylic acid. Commun. Soil Sci. Plant Anal. 6:71-80.

Curylo T., 1971. Effects of some factors on the uptake of magnesium by tobacco leaves. Acta Agr. Silv. (Series Agr.) 11:131.

D ord a s C., 2009. Foliar application of calcium and magnesium improves growth, yield, and essential oil yield of oregano (Origanum vulgare ssp hirtum). Industr. Crops Prod. 29: 599-608.

Ding Y.C., Chang C.R., Luo W., Wu Y.S., Ren X.L., Wang P., Xu G.H., 2008. High potassium aggravates the oxidative stress induced by magnesium deficiency in rice leaves. Pedosphere, 18(3): 316-327.

Embleton T.W., Jones W.W., 1959. Correction of magnesium deficiency of orange trees in California. Proc. Amer. Soc. Hort. Sci. 74: 280-288.

Escamilla Garcia J.L., Saucedo Veloz C., Martinez Damian M.T., Martinez Garza A., Sanchez Garcia P., Soto Hernandez R.M., 2003. Organic, mineral and foliar fertilization on development and production of papaya cv. Maradol. Terra, 21(2): 157-166.

Fisher E.G., Walker D.R., 1995. The apparent absorption of $\mathrm{P}$ and $\mathrm{Mg}$ from sprays applied to the lower surface of 'McIntosh' apple leaves. Proc. Amer. Soc. Hort. Sci. 65: 17-24.

Hafiz S.J., E1-Kholy M.A., 2001. Response of two lupine cultivars to phosphorus fertilization and foliar application of potassium and magnesium. Egypt. J. Agr. 22: 85-105.

Hailes K.J., Aitken R.L., Menzies N.W., 1997. Magnesium in tropical and subtropical soil from north - eastern Australia. II. Response by glasshouse-growth maize to applied magnesium. Aust. J. Soil Res. 35: 629641.

Houcheng Liu, Ximing Chen, Riyuan Chen, Shiwei Song, Guangwen Sun, 2006. Effects of magnesium deficiency on growth and photosynthesis of flowering chinese cabbage. XXVII Int. Hort. Congr./ SHS Acta Hort.: 767.

Michałojć Z., Szewczuk C., 2003. Teoretyczne aspekty dolistnego dokarmiania roślin. / Theoretical aspects of foliar nutrition. Acta Agrophys. 85: 9-17.

Mikiciuk M., Malinowska K., Wróbel J., 2008. Effect of magnesium nutrition under varying soil moisture, conditions of some physiological features of fragrant basil (Ocimum basilicum L.). Ecol. Chem. Engin. 15 (1-2): 93-102.

Mostafa E.A.M., Saleh M.M.S., Abd E1-Migeed M.M.M., 2007. Response of banana plants to soil and foliar applications of magnesium. Amer.- Eurasian J. Agric. Envir. Sci. 2 (2): 141-146. 
Moustafa Z.R., Omran S.E.H., 2006. Effect of foliar spray with boron or magnesium in combination with nitrogen fertilization on sugar beet plants. Egypt. J. Soil Sci. 46 (2): 115-129.

Orlovius K., 2001. Effect of foliar fertilization with magnesium, sulfur, manganese and boron to sugar beet, oilseed rape, and cereals. In W.J. Horst et al. (Eds.) Plant nutrition - Food security and sustainability of agro-ecosystem. Kluwer Acad. Publish.: 788-789.

Orłowski M., Kołota E., 1999. Uprawa warzyw. / Vegetable cultivation/ Wyd. Brasika, Szczecin: 118.

Pijanowski E., Mrożewski S., Horubała A., Jarczyk A., 1973. Technology of fruit and vegetable products. Państwowe Wydawnictwo Rolnicze i Leśne, W-wa: 132-134.

Pinkerton A., Person P.N., 1974. Effects of foliar application of magnesium sulphate on the quality and magnesium content of flue - cured tobacco. Aust. J. Exp. Agric. Animal Husb. 14: 677-683.

Sun O.J., Payn T.W., 1999. Magnesium nutrition and photosynthesis in Pinus radiata: clonal variation and influence of potassium. Tree Physiol. 19: 535-540.

Świerczewska M., Sztuder H., 2001. Response of cultivated plants to foliar magnesium fertilization. VIII. Międzynar. Symp. Ekol. Asp. Mech. Prod. Roślin. W-wa: 235-238.

Uziak Z., B orowski E., 1980/1981. Wpływ żywienia potasowego na produkcyjność i skład chemiczny roślin. / The influence of potassium nutrition on productivity and chemical content of plants. Ann. Univ. Mariae $\mathrm{Cu}-$ rie-Skłodowska 35/36, sect. E: 229-341.

\section{Wpływ dolistnego nawożenia szpinaku solami magnezu i mocznikiem na wymianę gazową, plon i jakość liści}

\author{
Streszczenie
}

W doświadczeniu wazonowym prowadzonym w fitotronie badano efektywność odżywiania dolistnego szpinaku (Spinacia oleracea $\mathrm{L}$.) różnymi solami magnezu bez i z dodatkiem $0,5 \% \mathrm{CO}\left(\mathrm{NH}_{2}\right)_{2}$. Magnez zastosowano 3-krotnie w formie roztworu $\mathrm{MgSO}_{4} \mathrm{x}$ $7 \mathrm{H}_{2} \mathrm{O}, \mathrm{Mg}\left(\mathrm{NO}_{3}\right)_{2}$ × $6 \mathrm{H}_{2} \mathrm{O}, \mathrm{MgCl}_{2} \times 6 \mathrm{H}_{2} \mathrm{O}, \mathrm{C} 4 \mathrm{H} 6 \mathrm{O} 4 \mathrm{Mg}$ x $4 \mathrm{H}_{2} \mathrm{O}$ wobec wody jako kontroli. Uzyskane wyniki wykazały, że dolistne odżywianie szpinaku nieorganicznymi solami magnezu jest skuteczną drogą uzupełniania poziomu $\mathrm{Mg}$ w roślinach w trakcie wegetacji. Zastosowanie natomiast kompleksu metalo-organicznego w postaci octanu magnezu $\left(\mathrm{C}_{4} \mathrm{H}_{6} \mathrm{O}_{4} \mathrm{Mg}\right.$ x $\left.4 \mathrm{H}_{2} \mathrm{O}\right)$ w stężeniu $1,7 \%$ mimo podobnego wpływu na zawartość $\mathrm{Mg}$ w liściach wywołało objawy fitotoksyczności w postaci chlorotycznych i nekrotycznych plam na liściach. Aplikacja roztworów nieorganicznych soli magnezu wpłynęła $\mathrm{w}$ istotnym stopniu na intensywniejszy przebieg wymiany gazowej liści (przewodność szparkową, transpirację, fotosynteza) i wzrostu plonu liści. Najbardziej efektywnie na wymienione procesy oddziaływał siarczan magnezu, natomiast negatywnie octan magnezu. Dolistne odżywianie szpinaku solami magnezu wpłynęło na wzrost zawartości białka, chlorofilu, karotenoidów, azotanów i proliny, a spadek zawartości witaminy $\mathrm{C}$ w liściach. Dodatek mocznika do aplikowanych roztworów soli magnezu zwiększał przebieg procesów wymiany gazowej roślin i zawartość w liściach białka, chlorofilu, karotenoidów, azotanów i proliny, zmniejszał natomiast zawartość witaminy $\mathrm{C}$, potasu i magnezu. 
